\title{
Cultural adaptation of the Child Feeding Questionnaire for use in Brazil
}

\author{
Adaptação cultural do Questionário de \\ Alimentação Infantil para uso no Brasil
}

\section{A B S T R A C T}

\section{Objective}

A methodological study aimed at performing the cultural adaptation of the Child Feeding Questionnaire for its use in Brazil.

\section{Methods}

We collected data in a city in the northeastern region of the state of São Paulo, between March and September 2018; seven judges assessed its language standardization, and 85 parents of preschool children performed the cultural adaptation.

\section{Results}

The judges' agreement level was above $80 \%$ for 54 of the 55 statements in the questionnaire. For the parents, the questionnaire is very good, they had no difficulties in using it; most of them understood the affirmative sentences and all

\footnotetext{
1 Universidade de São Paulo, Departamento de Enfermagem Materno-Infantil e Saúde Pública, Escola de Enfermagem de Ribeirão Preto. Av. Bandeirantes, n. 3900, Prédio Laboratórios Prof ${ }^{a}$ Neide Fávero, sala 21, Jd. Monte Alegre, 14040-902, Ribeirão Preto, SP, Brasil. Correspondence to: MCC FURTADO. E-mail: <mcandida@eerp.usp.br>.

2 Universidade de São Paulo, Faculdade de Medicina de Ribeirão Preto, Departamento de Puericultura e Pediatria. Ribeirão Preto, SP, Brasil.

Article based on the dissertation by R. A. SILVA, entitled "Adaptação cultural do Questionário de Alimentação Infantil (QAI) para uso no Brasil", Universidade de São Paulo; 2019.
}

How to cite this article

Silva RA, Monteiro JP, Santos CB, Silva MAI, Zucoloto ML, Furtado MCC. Cultural adaptation of the Child Feeding Questionnaire for use in Brazil. Rev Nutr. 2021;34:e190241. https://doi.org/10.1590/1678-9865202134e190241 
parents considered the questionnaire important for the knowledge of child's healthy eating. We estimated the internal consistency by considering the Kuder-Richardson coefficient for dichotomous variables, and the correlation of each item with the total score was also sought. The results showed values between 0.72 and 0.76 , indicating a good consistency, which confirms the reliability of the Brazilian version of the questionnaire.

\section{Conclusion}

The Child Feeding Questionnaire was culturally adapted, aided by the parents. Future studies must be conducted in other Brazilian realities to allow the questionnaire to be widely used. It contributes to promoting the implementation of better practices in child feeding that favor healthy growth and development, as well as to encourage healthy habits in Brazilian families, and to reduce overweight and childhood obesity in the country.

Keywords: Child nutrition. Knowledge. Obesity. Preschool. Validation study.

\section{R E S U M O}

\section{Objetivo}

Este estudo metodológico objetivou realizar a adaptação cultural do Questionário de Alimentação Infantil para uso no Brasil.

\section{Métodos}

Os dados foram coletados em município do nordeste paulista, entre março e setembro de 2018. Sete juízes avaliaram a padronização idiomática, e 85 pais de crianças em idade pré-escolar realizaram a adaptação cultural.

\section{Resultados}

Entre os juízes, obteve-se concordância acima de 80\% para 54 das 55 afirmações do questionário. Para os pais, o questionário é muito bom; não há dificuldade em utilizá-lo; a maioria compreendeu as frases afirmativas; e todos o julgaram de grande importância para o conhecimento da alimentação saudável da criança. A consistência interna foi estimada considerando o coeficiente Kuder-Richardson para variáveis dicotômicas; buscou-se também a correlação de cada item com o total. Obtiveram-se valores entre 0,72 e 0,76, ou seja, boa consistência, o que confirma a fidedignidade da versão brasileira do questionário.

\section{Conclusão}

O Questionário de Alimentação Infantil foi adaptado culturalmente com pais. Estudos futuros devem ser conduzidos em outras realidades brasileiras para permitir a ampla utilização do questionário. Ele contribui para fomentar a implementação de melhores práticas na alimentação infantil que favoreçam crescimento e desenvolvimento saudáveis, assim como para estimular hábitos saudáveis nas famílias brasileiras e a redução dos quadros de sobrepeso e obesidade infantil no país.

Palavras-chave: Nutrição da criança. Conhecimento. Obesidade. Pré-escolar. Estudo de validação.

\section{INTRODUCTION}

To invest in children and defend their rights in early childhood, Brazilian food policies include health care agreements, with one of the commitments aimed at food, the focus of this investigation $[1,2]$. The Strategic Axis II - Breastfeeding and Complementary Healthy Eating argues for a high standard of child health through timely nutrition and the acquisition of foods that are safe and have adequate nutrients [2].

Scientific evidence reinforces that, despite the well-known benefits of breastfeeding for the child, it is still rarely exclusively offered until the age of six months and the introduction of foods persists, not in accordance with international recommendations [3-9]. Thus, studies postulate that it is necessary to understand the parents' knowledge about their children's healthy eating habits [4,7-11].

The "Child Feeding Questionnaire" (CFQ) was developed by Portuguese researchers to be used with preschool children and to find out notions and knowledge about child feeding [12]. It contains 55 statements 
about foods and food groups, it is self-applicable, with statements distributed in four dimensions, namely "Food and Health", "Food Rules", "Family Food Beliefs" and "Variety/Diversity in Food Pattern".

Scores are zero (0) or one (1), respectively for incorrect answers (inadequate knowledge) and correct answers (adequate knowledge) [12]. The total score is the sum of all correct answers. The parents' knowledge about the child's diet is considered better when the total score is higher. The level of knowledge is classified by means of cut-off groups on each factor, using the formula (Mean \pm 0.25 standard deviation) and results that indicate: Insufficient, Sufficient, and Good Knowledge [12].

The offer of appropriate foods that are beneficial to the growth and development of Brazilian children, together with the scientific evidence on the importance of promoting healthy lifestyle habits, starting with the introduction of food and, also, due to the lack of Brazilian instruments validated to find out how much parents know about their children's healthy eating, this study aims to culturally adapt the CFQ for use in Brazil [1-11].

\section{METHODS}

This methodological study covered, between March and September 2018, the stages indicated in the reference [13] and covers the: idiomatic standardization of the instrument; assessment by a committee of experts; back-translation; patient panel; adapted version of the instrument and pilot test [13]. The CFQ comes from a language also spoken in Brazil; thus, the term idiomatic standardization was used for cultural adaptation, used by researchers at a university in the state of São Paulo and which indicates the maintenance of the instrument's understanding after cultural adaptation to the same language, however, in different countries [14].

Two professionals with knowledge of the Portuguese language individually analyzed idiomatic standardization and the respective adjustments of the original CFQ. Thus, two versions were obtained with maintenance of conceptual and non-linguistic equivalence, and proportionality between the original version and the idiomatic standardized version. Inaccurate items that could cause strangeness when mentioned were identified and, after returning these versions, the material was synthesized. For the expert committee, seven experts were selected by the integration of different curriculum database platforms, contacted via e-mail, and filled out validation forms in a free app for online forms.

The agreement level was above $80 \%$ for 54 of the 55 statements of the CFQ. However, word modifications were pointed out and accepted as they maintained the meaning of some sentences. Because item 19 indicates a kind of food (bolicao, a sweet and fluffy bread stuffed with chocolate) that does not exist in Brazil (nor is there a similar), there was consensus among experts and authorization by the author to replace it with sonho (fried dough stuffed with Italian custard cream or milk jam)/donuts, as it has equivalence in caloric and nutritional properties.

In the back-translation, two Portuguese-speaking professionals who did not know the objective of the research or the CFQ delivered their translations to the original language. When comparing with the idiomatic standardization, equivalence was found between the versions, in addition to the need to revise the term used in item 19 (sonho/donuts), which has another meaning in Portugal. The author of the CFQ allowed it to be changed for "bisnaguinha type bread with chocolate filling", closer to the Brazilian reality and with nutritional values corresponding to the food originally indicated in this item.

Patient panel is the term used in the references, whose step was intended to characterize the semantics of words, to perform a comprehension analysis, that is, to analyze whether the translated instrument is 
understandable in the reality of the country where it should be applied [13]. Here, the use of the CFQ with parents of preschoolers stands out, with the maintenance of the expression panel of patients, in order to meet the methodological framework [13].

In this way, the patient panel sought to characterize the semantics of the words and verify whether the translated CFQ is understandable for the Brazilian reality. We chose to complement the semantic validation step of the framework used with questionnaires adapted by a research group, such as the General Impression Sheet - universally assessing the CFQ - and the Specific Semantic Validation Sheet - assessing the understanding of each item of the CFQ for the semantic validation step [13,15].

In this stage, 30 parents (target audience) of preschoolers enrolled in one of the 33 Children's Community Centers (CCC) participated with the highest number of places for this age group in a medium-sized municipality in the northeast of São Paulo. They were divided into subgroups for the application of the questionnaires, according to the manual [15]. The criteria for the selection of participants were: being the parent of a preschool child; being the child's primary caregiver (that is, this person is responsible for the child and knows his food consumption); the child is enrolled at the CCC. The approach was carried out randomly on alternate days during the week. Parents were invited to the research at the entrance and exit of their child at the CCC, and upon acceptance, they signed the Informed Consent Form, after that the CFQ and the questionnaires from the semantic validation stage were applied. It was verified whether they understood all items; however, item 08 - "Lunch and dinner meals should start with soup rich in vegetables" was changed to "Lunch and dinner meals should be rich in vegetables", since, in the original version, the statement is not compatible with the reality of Brazilian families. Due to the tropical climate for most of the year, vegetables (in the form of soup) are not given to children. The author of the CFQ consented to this change by maintaining the psychometric measures of the original item.

After the final adjustments to the adapted version of the CFQ, the pilot test was carried out for further information regarding the psychometric properties. For this stage, a new selection of parents was carried out and the same methodology as the patient panel was used, considering the eligibility, approach, and invitation to the participants. The CFQ was self-applied and each participant answered 55 statements as true or false.

To analyze the data in an exploratory and broad way through absolute and relative frequencies, the Kuder-Richardson coefficient (KR20) was used, and the items were correlated with the total score. The KR20 reflects the degree of covariance between the elements of a scale and, for this, the smaller the sum of the variance of the items, the more consistent the instrument is considered. The veracity of the results is considered for values greater than 0.7 [16]. The Research Ethics Committee of the Escola de Enfermagem Ribeirão Preto at the Universidade de São Paulo approved the research under opinion n. 2,483,310. All participants (judges and parents) signed the ICF.

\section{RE S U L T S}

Of the 30 parents, the majority referred to the CFQ as very good, having no difficulty in using it and understanding the statements contained therein; all parents indicated it as very important (Table 1).

The specific semantic validation for each item was applied with 30 parents. Each of them received a subgroup of 11 items to answer and the percentages obtained were higher than $92 \%$ for a good understanding of the CFQ items. The pilot test with 55 parents showed that the CFQ was well accepted. The application of the KR20 coefficient resulted in values between 0.72 and 0.76 for the 55 items of the questionnaire, which means good consistency and demonstrates the reliability of the Brazilian version of the CFQ. 
Table 1 - Classification of parents according to responses (General Impressions Sheet). Semantic validation stage of the Child Feeding Questionnaire instrument. Franca (SP), Brazil, 2018.

\begin{tabular}{|c|c|c|}
\hline Variables & $\mathrm{n}$ & $\%$ \\
\hline \multicolumn{3}{|l|}{ General analysis } \\
\hline Very good & 22 & 73.4 \\
\hline Good & 8 & 26.6 \\
\hline Regular & - & - \\
\hline \multicolumn{3}{|l|}{ Utilization } \\
\hline No difficulty & 28 & 93.4 \\
\hline Some difficulties & 2 & 6.6 \\
\hline Many difficulties & - & - \\
\hline \multicolumn{3}{|l|}{ Comprehension } \\
\hline All questions were easy & 23 & 76.6 \\
\hline Some questions were easy & 7 & 23.4 \\
\hline All questions were difficult & - & - \\
\hline \multicolumn{3}{|l|}{ Importance } \\
\hline Very important & 30 & 100 \\
\hline Sometimes important & - & - \\
\hline Not important at all & - & - \\
\hline
\end{tabular}

Note: $n=30$.

\section{DISCUSSION}

The initial steps and procedures for adapting the CFQ to the Portuguese language in Brazil, as indicated in this study, point to the relevance in preserving the quality of the instrument and ensures the reliability and quality of the information, which can be used in future studies, since the cultural characteristics of Brazil proved to be relevant. In several areas of health, assessment questionnaires are frequent tools, as they help diagnosis, improving treatment and quality of life $[17,18]$.

In Brazil, there is no instrument like the CFQ; therefore, adapting or validating an instrument already outlined and validated in another country, and not building a new one, cooperates to save time, costs, and facilitates the comparison of findings from other investigations implemented in different circumstances [19]. In the stages covered, expressions were changed to terms that are more in line with the Brazilian reality; however, its meaning was maintained and its replacement was authorized by the author of the original CFQ. Even with the methodological rigor in conducting cultural adaptation, it is necessary to verify how the target audience understands the items in the semantic validation stage. If the researchers identify that misunderstandings still occur in any item or that it does not match what was expected by the researchers, the item must be revised or adapted [20].

The semantic validation adjusts the instrument to the language of interest, not only enabling the identification of the level of understanding for each item, but also adjusting the answers for which the instrument was built [21]. Still, reliability is an important psychometric property, as it indicates the consistency, accuracy, and stability of the instrument; it means that it ensures that the instrument measures the object to which it is proposed in a reproducible way [22-25].

For the psychometric properties, the pilot test included parents of preschoolers and assessed the reliability and internal consistency of the version adapted for Brazil. Researches recommend that instruments or multidimensional scales (with more than one dimension) have good internal consistency, certifying that the items composed in the different dimensions of a measure are strongly correlated $[16,22]$. 
Finally, assessing the reliability of a measure using an appropriate marker allows the examination of the accuracy of the instrument $[16,22]$. Therefore, the reliability of the CFQ, in its Brazilian version, was verified through its internal consistency, resulting in values above 0.70 , corroborating the other authors' recommendations [23].

\section{CONCLUSION}

The cultural adaptation of the CFQ for Brazil resulted in a good acceptance, being easily understood by the participants. The version was culturally adapted and proved to be reliable for assessing the parents' knowledge about healthy eating for preschoolers.

Future studies should be conducted in other Brazilian realities to allow this instrument to be widely used by professionals who work with children in this age group, to verify the degree of knowledge of their parents. And, based on the results, implement better child feeding practices that favor a healthy growth and development. In addition to this, there is the opportunity to stimulate, in families, the process of forming and maintaining healthy habits, which can be a reducer for overweight and childhood obesity in the country.

\section{CONTRIBUTORS}

RA SILVA and MCC FURTADO participated in the conception and design, analysis and interpretation of data, review and approval of the final version of the article. JP MONTEIRO, CB SANTOS, MAI SILVA, and ML ZUCOLOTO participated in the review and approval of the final version.

\section{REFERENCES}

1. Venâncio SI. Why invest in early childhood? Rev Latino-Am Enferm. 2020;28:e3253. https://doi.org/10.1590/15188345.0000-3253

2. Ministério da Saúde (Brasil). Política Nacional de Atenção Integral à Saúde da Criança: orientações para implementação. Brasília: Ministério; 2018[citado 1 dez 2019]. Disponível em: https://portaldeboaspraticas.iff.fiocruz.br/wp-content/ uploads/2018/07/Pol\%C3\%ADtica-Nacional-de-Aten\%C3\%A7\%C3\%A3o-Integral-\%C3\%A0-Sa\%C3\%BAdeda-Crian\%C3\%A7a-PNAISC-Vers\%C3\%A3o-Eletr\%C3\%B4nica.pdf

3. Jurado LS, Báez MVJ, Juárez SO, Olvera TC. Breastfeeding, complementary feeding and risk of childhood obesity. Aten Primaria. 2016;48(9):572-8. https://doi.org/10.1016/j.aprim.2015.10.004

4. Campoy C, Campos D, Cerdó T, Diéguez E, García-Sanros JA. Complementary feeding in developed countries: the 3 Ws (when, what, and why?). Ann Nutr Metabol. 2018;73(Suppl1):27-36. https://doi.org/10.1159/000490086

5. Roess AA, Jacquier EF, Catellier DJ, Carvalho R, Lutes AC, Anater AS. et al. Food consumption patterns of infants and toodlers: findings from the Feeding Infants and Toodlers Study (FITS) 2016. J Nutr. 2018;148(Suppl3):1525S-35S. https://doi.org/10.1093/jn/nxy171

6. Walters CN, Rakotomanana H, Komakech JJ, Stoecker BJ. Maternal determinants of optimal breastfeeding and their association with child undernutrition in Malawi (2015-2016). Bmc Public Healthy. 2019;19:1503. https://doi. org/10.1186/s12889-019-7877-8

7. Arikpo D, Edet ES, Chibuzor MT, Odey F, Caldwell DM. Educational interventions for improving primary caregivers complementary feeding practices for children aged 24 months and under. Cochrane Database Syst Rev. 2018;(5). https://doi.org/10.1002/14651858.CD011768.pub2

8. Wang L, Van Grieken A, Van der Velde LA, Vlasblom E, Beltman M, L'Hoir MP. Factors associated with early introduction of complementary feeding and consumption of non-recommended foods among Dutch infants: the BeeBOFT study. Bmc Public Health. 2019;19:388. https://doi.org/10.1186/s12889-019-6722-4 
9. Nicklas TA, O'Neil CE, Fulgoni VL. Nutrient intake, introduction of baby cereals and other complementary foods in the diets of infants and toddlers from birth to 23 months of age. Aims Public Health. 2020;7(1):123-47. https:// doi:10.3934/publichealth.2020012

10. Nittari G, Scuri S, Petrelli F, Pirillo I, Di Luca NM, Grappasonni I. Fighting obesity in children from European World Health Organization member states: epidemiological data, medical-social aspects, and prevention programs. Clin Ter. 2019;170(3):e223-30. https://doi.org/10.7417/CT.2019.2137

11. Pérez-Herrera A, Cruz-López M. Childhood obesity: current situation in Mexico. Nutr Hosp. 2019;36(2):463-9. https://doi.org/10.20960/nh.2116

12. Costa MGFA, Nunes MMJC, Duarte JC, Pereira MAS. Parents' knowledge about feeding: construction and validation of a child feeding questionnaire. Rev Enferm. 2012;3(6):55-68. https://doi.org/10.12707/RIII1158

13. Ferrer M, Alonso J, Prieto L, Plaza V, Monsó E, Marrades R, et al. Validity and reliability of the St George's Respiratory Questionnaire after adaptation to a different language and culture: the Spanish example. Eur Resp J. 1996;9:1160-6. https://doi.org/10.1183/09031936.96.09061160

14. Felipe HR. Validation of the forensic nursing practice questionnarie [thesis]. Ribeiro Preto: Universidade de São Paulo; 2017.

15. Disabkids Group. Translation and validation procedure: guidelines and documentation form. Leiten: The Disabkids Group; 2004.

16. Maroco J, Garcia-Marques T. Qual a fiabilidade do alfa de Cronbach? Questões antigas e soluções modernas? Lab Psico. 2006;4(1);65-90. https://doi.org/10.14417/LP.763

17. Fortes CPDD, Araujo APQC. Check list for healthcare questionnaires cross-cultural translation and adaptation. Cad Saúde Coletiva. 2019;27(2):202-9. https://doi.org/10.1590/1414-462×201900020002

18. Chaves FA, Cecilio SG, Reis IA, Pagano AS, Torres HC. Translation and cross-cultural adaptation of the Behavior Change Protocol for educational practices in Diabetes Mellitus. Rev Latino-Am Enferm. 2019;27:e3164. https://doi. org/10.1590/1518-8345.2908.3164

19. Galdeano LE, Furuya RK, Delacio MCB, Dantas RAS, Rossi LA. Validação semântica do Cardiac Patients Learning Needs Inventory para brasileiros e portugueses. Rev Gaúcha Enferm. 2011;32(3):602-10. https://doi.org/10.1590/ S1983-14472011000300024

20. Cassepp-Borges V, Balbinotti MAA, Teodoro MLM. Tradução e validação de conteúdo: uma proposta para a adaptação de instrumentos. In: Pasquali L, editor. Instrumentação psicológica: fundamentos e práticas. São Paulo: Jones \& Bartlett; 2010.

21. Silva LMC, Surniche CA, Sicsú AN, Mitano F, Nogueira JA, Santos CB, et al. Design and semantic validation of a new instrument to assess policy transfer of directly observed treatment for tuberculosis. Rev Panam Salud Publica. 2015;38(2):129-35.

22. Fayers PM, Machin D. Scores and measurements: validity, reliability, sensitivity. In: Fayers PM, Machin D. Quality of life: assessment, analysis and interpretation. New York: Wiley; 2007.

23. Terwee CL, Roorda LD, Vet HCW, Dekker J, Westhovens R, Van Leeuwen J, et al. Dutch-Flemish translation of 17 item banks from the patient-reported outcomes measurement information system (PROMIS). Qual Life Res. 2014;23(6):1733-41. https://doi.org/10.1007/s11136-013-0611-6

24. Romeiro V, Bullinger M, Marziale MHP, Fegadolli C, Reis RA, Silveira RCCP, et al. DISABKIDS ${ }^{\circledR}$ in Brazil: advances and future perspectives for the production of scientific knowledge. Rev Latino-Am Enferm. 2020;28:e3257. https://doi. org/10.1590/1518-8345.3003.3257

25. Batista MJ, Marques ACP, Silva Junior MF, Alencar GP, Sousa MLR. Translation, cross-cultural adaptation and psychometric evaluation of Brazilian Portuguese version of the 14-item Health Literacy Scale. Ciênc Saúde Coletiva. 2020;25(7):2847-57. https://doi.org/10.1590/1413-81232020257.22282018 